\title{
An Extension of the Experiments of Kunio Kondo and Taro Tajima with Stereo Vision Without Optical Aid* by David W. Brisson**
}

\section{ABSTRACT}

The following paper is an extension of the stereo principles used by Kondo and Tajima in their article in the Journal of Graphic Science of Japan, No.28, p.1. These basic ideas are well-known in their simple form as stereograms, and have been adapted as hyperstereograms by Brisson for the American Association for the Advancement of Science Annual Conference in Washington, D.C. in 1978. However, the work of Kondo and Tajima is interesting and well conceived. A particularly interesting aspect of their work concerns the arrays of stereographic elements that they have generated. They have produced the basis of stereo effects from single image construction. This paper is a discussion of some of the possibilities of that aspect.

Figure 1 is figure 8 from Kondo and Tajima's article: "Experiment of Stereo vision Without Optical Aid" from the Journal of Graphic Science of Japan No. 28, p.1. Figure 2 is an ordinary stereogram of a cube, from an article by Brisson in the Proceeding of the International Conference on Descriptive Geometry, Vancouver, 1978. Figure 3 is a drawing by Brisson, demonstrating how to view a stereogram. The method is basically to cross one's eyes in front of the stereogram such that the left image of the cube as projected upon the right eye is superimposed upon the right image of the cube as projected upon the left eye, with the result being the subjective "fusion" of the two images into a little three-dimensional cube floating in front of the paper, between the viewer and the paper. Kondo and Tajima give very fine examples of such stereo images.

Now, one evening several years ago, while trying to get to sleep in a strange room in New Brunswick, Canada, while on a trip, I was surprised to observe that the wallpaper appeared to be three-dimensional. I started up out of a semi dream-state a little alarmed, and looking carefully at the wall-paper, it seemed perfectly ordinary, 
consisting of a rather ordinary pattern of rosebuds in a geometric array. I started to doze off again and again was alarmed to see the wallpaper become three-dimensional again. This time I considered it more carefully. Apparantly, since each rosebud was identical with every other rosebud, and they were ordered in such a simple array, it was possible to cross my eyes and line up the rosebuds several inches in front of the wall surface. Trying this now on purpose, it was quite easy to do, and sure enough, the array of rosebuds could be made to float in a plane several inches in front of the wall surface. I was then able to settle down to sleep.

Figure 1, of Kondo and Tajima brought back that experience to mind and it occurred to me to try the same thing with their array. Sure enough, by crossing one's eyes while looking at their single image it is possible to construct in one's mind a whole array of completely three-dimensional little boxes, similar to the rosebuds, but this time a little three-dimensional form as each element.

In relation to this, I had noticed while lying on my couch in my living room at home, that the squares in my paneled ceilings could be made to appear at different levels above me by crossing my eyes, again similar to the rosebuds, thus the reader may be able to see the set of lines in Figure 4 at different levels. The single dot may assist at this. By making the dot "double" optically, one can control the distance of the set of lines above the paper.

Now, the most interesting aspect of this is the possibility of constructing fully stereo images with a single image. Certainly Kondo and Tajima's array is one form of this. However, I suggest a more basic structure. Figure 5 shows an array of lines that change their distance from each other by perspective projective methods, as shown in the figure.

Now, by viewing these lines as we have viewed the other arrays there are a number of possible fully three-dimensional interpretations. In fact, the first experince is one of confusion. After a little practice, it will be seen that it is possible to view this array in such a way that it appears to be a set of lines in a flat plane that intersects the paper and extends as an angle outward!

It is clear that Kondo and Tajima, by showing their whole array, have opened up the possibility of the single, fully stereo image. 
国四
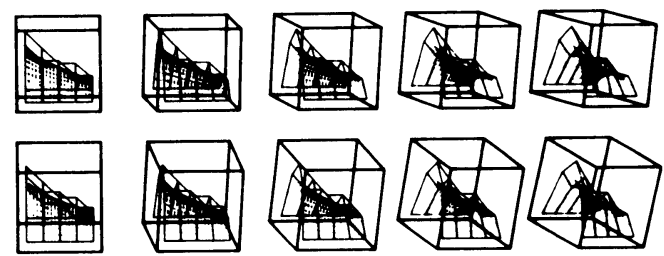

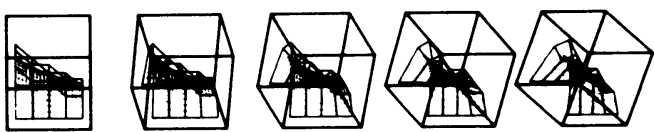

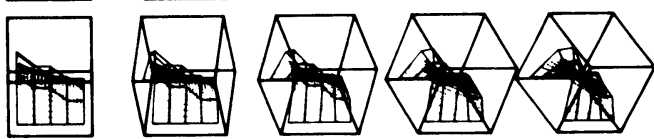

Figure 1
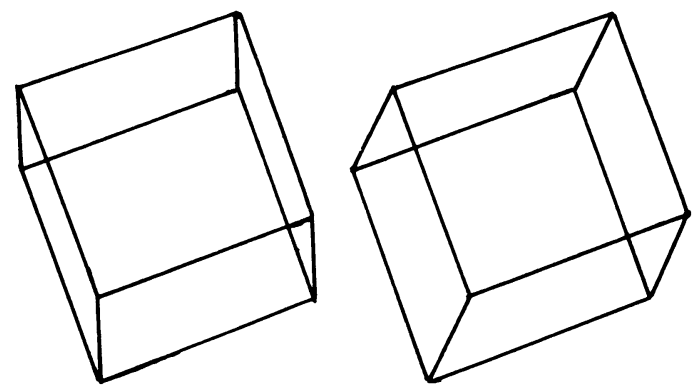

Figure 2

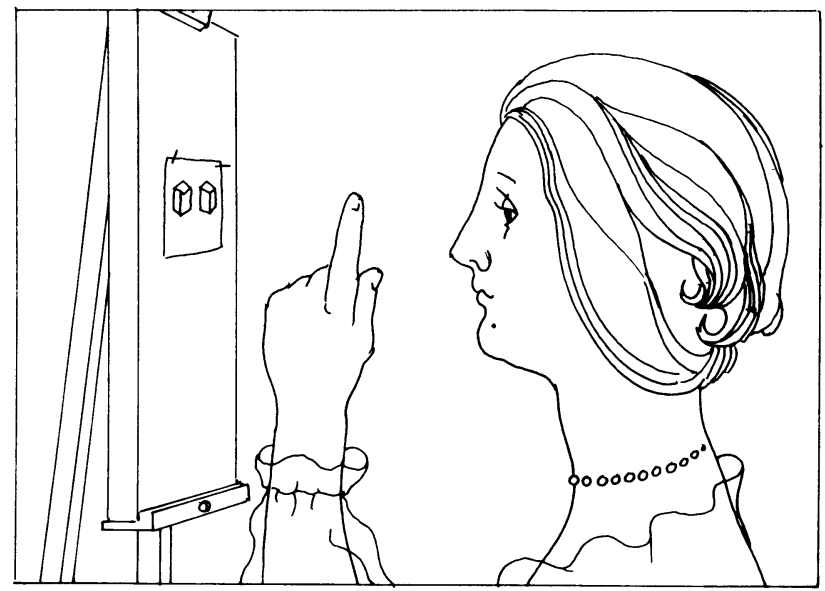

Figure 3 


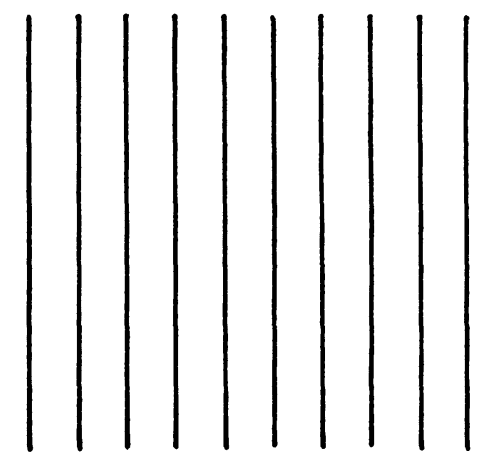

Figure 4

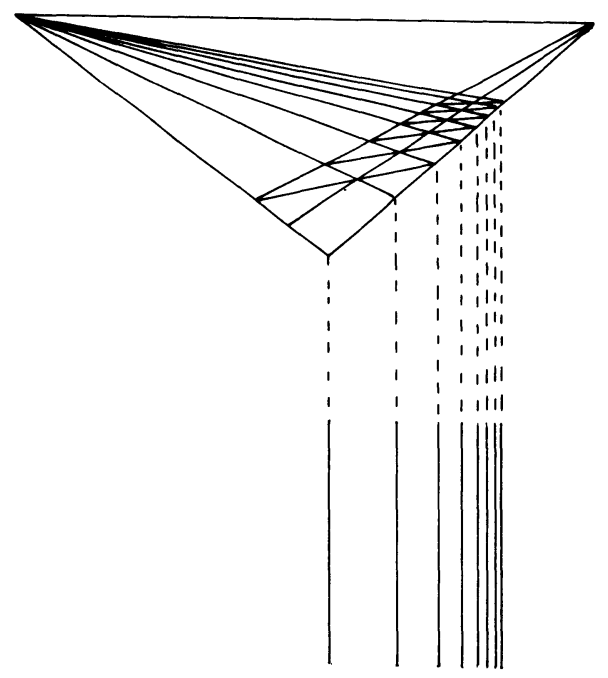

Figure 5

\section{（邦文総括） 肉眼立体視に関する近藤・田嶋の実匰の一つの拡張}

この論文は日本図学会誌 No.2 8, P. 1 亿掲載されている近藤・田嶋氏の論文のなかで両氏が 用いているステレオの原理の一つの拡張である。その原理の基本的な考えは，S ter eogram の 簡単な形式としてよく知られており，1978 年Washington，D．C．における米国科学振興 年次会議でBrisson によって Hyperstereogram として応用された。しかし近藤・田嶋両氏 の研究は面白く，またよく考案されたものである。乙の研究の特に関心を引く部分は，彼等の考 え出した立体視図の配置関する箇所である。彼等は単純なイメージ構成からステレオ効果の基 礎を導いている。私の論文はその部分の可能性についてのいくつかの考察である。 